\title{
FOMC Learning and Productivity Growth (1985-2003): A Reading of the Record
}

\author{
Richard G. Anderson and Kevin L. Kliesen
}

\begin{abstract}
The increasingly rapid productivity growth that began in the 1990s was the defining economic event of the decade and a major topic of debate among Federal Reserve policymakers. A key aspect of the debate was the contrast between information contained in aggregate data, which initially suggested little productivity gain, and anecdotal firm-level evidence, which hinted at the productivity acceleration. The authors revisit this debate from the actual FOMC transcripts. Their study illustrates the process by which policymakers filter incoming data to identify changes in underlying fundamental trends. (JEL E52, E58)
\end{abstract}

Federal Reserve Bank of St. Louis Review, March/April 2010, 92(2), pp. 129-53.

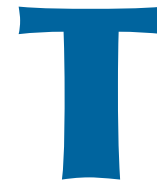

his analysis, based on public verbatim transcripts of Federal Open Market Committee (FOMC) meetings, explores how the members of the FOMC adapted monetary policy from 1983 to 2003 in response to changing productivity growth. ${ }^{1} \mathrm{~A}$ major challenge in monetary policymaking is recognizing changes in economic trends as they occur, that is, learning. ${ }^{2}$ Thomas Sargent has explored, in a number of articles, how policymakers who begin with a flawed (or incomplete) model can, with experience through learning, converge on an "approximate but good enough" model of the economy. ${ }^{3}$ The productivity acceleration is too recent for us to assess whether this occurred

1 The FOMC transcripts, searchable by meeting date, are available on the website of the Board of Governors of the Federal Reserve System (www.federalreserve.gov/monetarypolicy/fomc historical.htm).

2 Almost all histories of the Federal Reserve contain some element of policymakers learning about and responding to a changing economy (e.g., see Meltzer, 2003, and Friedman and Schwartz, 1963).

3 See, for example, Sargent (2001) and papers cited therein. during that period; we leave that as a topic for future research.

In January 2004, Chairman Greenspan summarized the role of the productivity revolution in FOMC policymaking in a speech at the American Economic Association meeting (Greenspan, 2004):

The rise in structural productivity growth was not obvious in the official data on gross product per hour worked until later in the decade, but precursors had emerged earlier. The pickup in new bookings and order backlogs for high-tech capital goods in 1993 seemed incongruous given the sluggish economic environment at the time. Plant managers apparently were reacting to what they perceived to be elevated prospective rates of return on the newer technologies, a judgment that was confirmed as orders and profits continued to increase through 1994 and 1995. Moreover, even though hourly labor compensation and profit margins were rising, prices were being contained, implying increasing growth in output per hour.

Richard G. Anderson is a vice president and economist in the Research Division and Kevin L. Kliesen is an economist in the Banking Supervision and Regulation Division at the Federal Reserve Bank of St. Louis. The authors thank Charles S. Gascon, Yang Liu, and Tom A. Pollmann for research assistance. Richard G. Anderson thanks Janna Kritz for helpful discussions regarding historical events and the Research Department of the Federal Reserve Bank of Minneapolis for its hospitality during research for parts of this article.

(C) 2010, The Federal Reserve Bank of St. Louis. The views expressed in this article are those of the author(s) and do not necessarily reflect the views of the Federal Reserve System, the Board of Governors, or the regional Federal Reserve Banks. Articles may be reprinted, reproduced, published, distributed, displayed, and transmitted in their entirety if copyright notice, author name(s), and full citation are included. Abstracts, synopses, and other derivative works may be made only with prior written permission of the Federal Reserve Bank of St. Louis. 
As a consequence of the improving trend in structural productivity growth that was apparent from 1995 forward, we at the Fed were able to be much more accommodative to the rise in economic growth than our past experiences would have deemed prudent. We were motivated, in part, by the view that the evident structural economic changes rendered suspect, at best, the prevailing notion in the early 1990s of an elevated and reasonably stable NAIRU [non-accelerating inflation rate of unemployment]. Those views were reinforced as inflation continued to fall in the context of a declining unemployment rate that by 2000 had dipped below 4 percent in the United States for the first time in three decades.

Recent empirical studies confirm that FOMC decisions under Chairman Greenspan's leadership resembled an exercise in risk management. Killian and Manganelli (2008), for example, conclude that FOMC decisions during his tenure are "better described in terms of the Fed weighing upside and downside risks to their objectives rather than simply responding to the conditional mean of inflation and the output gap"; further, they reject the familiar hypothesis that FOMC decisions were consistent with a generalized Taylor rule based on expected utility maximization with quadratic and symmetric preferences in inflation and output.

The nearest antecedent to our analysis is Blinder and Reis (2005), who use a Taylor rulelike framework to formalize the concept of a "Greenspan standard" that "cherishes option value" and "pure period-by-period discretion."4 Our analysis, at least in part, extends that of Blinder and Reis.

\section{THE DATA}

At each FOMC meeting, members' decisions are informed by (i) the staff's summary of incoming published data and (ii) the staff forecast. Figures $1 \mathrm{~A}$ and $1 \mathrm{~B}$ compare forecasts of labor productivity growth at four-quarter and one-

4 Taylor (2005) stresses that the "Taylor rule" embodies general principles of good policymaking as much as it is a proscriptive policy rule. In this sense, Greenspan followed a Taylor rule-like regime. quarter, horizons, respectively, with the corresponding first-published observed values. Staff forecasts during the early 1980s overpredicted productivity growth after the 1980 recession ended and underpredicted growth during the subsequent slowdown. Staff projections also missed a turning point at the start of the 1990 recession and the productivity acceleration that began in 1995. By 1998, staff projections of productivity growth tended to increase, tracking incoming published data. Staff forecasts tracked productivity well during the post-2000 recession-but failed to capture the later acceleration. The forecast errors are not symmetric; the staff forecasts more often (and by larger amounts) underpredicted rather than overpredicted productivity growth.

Figure 2 displays staff forecasts and initially published data for real gross domestic product (GDP), an essential part of the productivity forecast. It is evident that forecast misses in predicting output growth caused a large part of the misses in predicting labor productivity - the forecast error patterns are similar both at the four-quarter (Figure 2A) and one-quarter horizons (Figure 2B). Because the FOMC was concerned with gross national product (GNP), not GDP, during the 1980s, for completeness Figures 3A and 3B display real GNP for that period; the conclusion is unchanged.

\section{THE 1980s}

The ability of information and communications technology (ICT) to increase productivity was widely acknowledged during the "high-tech" boom of the 1980s-Wynne (2002), for example, notes that a computer was Time magazine's "Man of the Year" in 1982. Discussions of productivity appear frequently in the FOMC transcripts as early as 1983, focused on separating cyclical from trend productivity growth and correctly measuring productivity growth in the services-producing sector. Most often, staff projections of trend growth extrapolated the 1970s 1 to $1 \frac{1}{2} 2$ percent pace. At the May 1983 meeting, for example, the staff projected near-term productivity growth at a $3^{1 / 2}$ 
percent annual rate, reflecting cyclical effects; trend growth was projected at a 1 percent rate during 1983 , increasing to $1 \frac{1 / 4}{4}$ to $1 \frac{1 / 2}{2}$ percent for 1984-a pace that Chairman Volcker labeled "pessimistic." In their defense, the staff noted that they had increased their projection from a previous $3 / 4$ of 1 percent rate. At the July meeting, the staff maintained the same projection, "just a little over 1 percent" to "in the 11/4 percent range." Committee members during the 1980s increasingly requested the staff to quantify the degree of uncertainty in their estimates, especially any downward bias-in counterpoint, members offered anecdotes from both the manufacturing and service sectors to suggest that the staff estimates were low. At the May 1984 meeting, for example, President Frank E. Morris (Boston Fed) and Chairman Volcker noted that the capital-goods boom underway was substantially "all electronics" and hence augured well for productivity gains. The staff, however, held fast to their forecast of modest labor productivity growth.

At the July 1984 meeting, trend productivity growth again was projected at a $1^{1 / 4}$ percent pace. President Morris cited anecdotal evidence that firms were expecting "extraordinarily high productivity" from new capital, consistent with the perceived high cost of capital funding. The staff defended their projected 11/4 percent trend productivity growth rate by noting that it was twice the then-estimated 0.6 percent pace of the 1970s.

The discussion of the services-producing sectors at the November 1983 meeting was typical for the FOMC: President Theodore H. Roberts (St. Louis Fed) asked whether the economy's shift toward services and away from manufacturing was adequately incorporated in staff projections:

On the productivity [issue]. I guess you took into account this major change from manufacturing to services in the 1970s as one of the factors holding back productivity. With services now such a large part of the economy, would that from here on out tend to cause the same or an increased rate of productivity if it stabilized, let's say?

The staff response highlighted the risk of measurement error:
The bulk of the research that was done, as we discussed earlier, was unable to pin that down for the 1970s. Most of the research showed that productivity slowed in service industries as well as in manufacturing industries. The pattern of the slowdown was at least the same across different types of industries, so we were unable to pin this productivity slowdown on the growing services sector. Looking ahead and having the services sector be one of the growing sectors, I'm not sure that that should detract from the things that seem to be important in the productivity slowdown. However undefined they may be. There are some technological changes that could affect the services sector as well as manufacturing.

President Roberts responded by asserting his belief that the services sector was beginning to experience increased productivity- "for the short run anyway." Skeptical members pressed the argument that service-sector data were plagued by mismeasurement. Subsequent data seemed to offer more support to skeptical Committee members than to the staff. At the September 1986 meeting, for example, Governor Wayne Angell argued: "Productivity in the service sector is low but I don't think we know how to measure it. Productivity in the goods producing sector remains right at the 3.2 percent level that it has been at for some time.” Both Governor Angell and Chairman Volcker continued their criticism at the following meeting (November 1986). The staff acknowledged that incoming data for the manufacturing sector suggested "fairly substantial increases in productivity...For this cycle the gains are much more favorable in comparison to past cyclical experience than for the rest of the economy.” Governor Angell repeated his suspicion of the measurements:

Of course, what this means-and I've had several conversations with our staff over thisis that, with productivity in manufacturing doing what it is and the way we go about measuring it, we have to have negative productivity in the service sector. And that raises the question as to how we measure productivity in the service sector; the fact of the matter is that we really don't. So there is some kind of strange averaging process going on there. I think there's really grave doubt as to what our productivity in the service sector is. But if productivity in 
Figure 1A

\section{Labor Productivity, Nonfarm Business Sector: Initial Published Data and Forecast Error (Increase During the Next Four Quarters, Percent Annual Rate, Quarterly)}

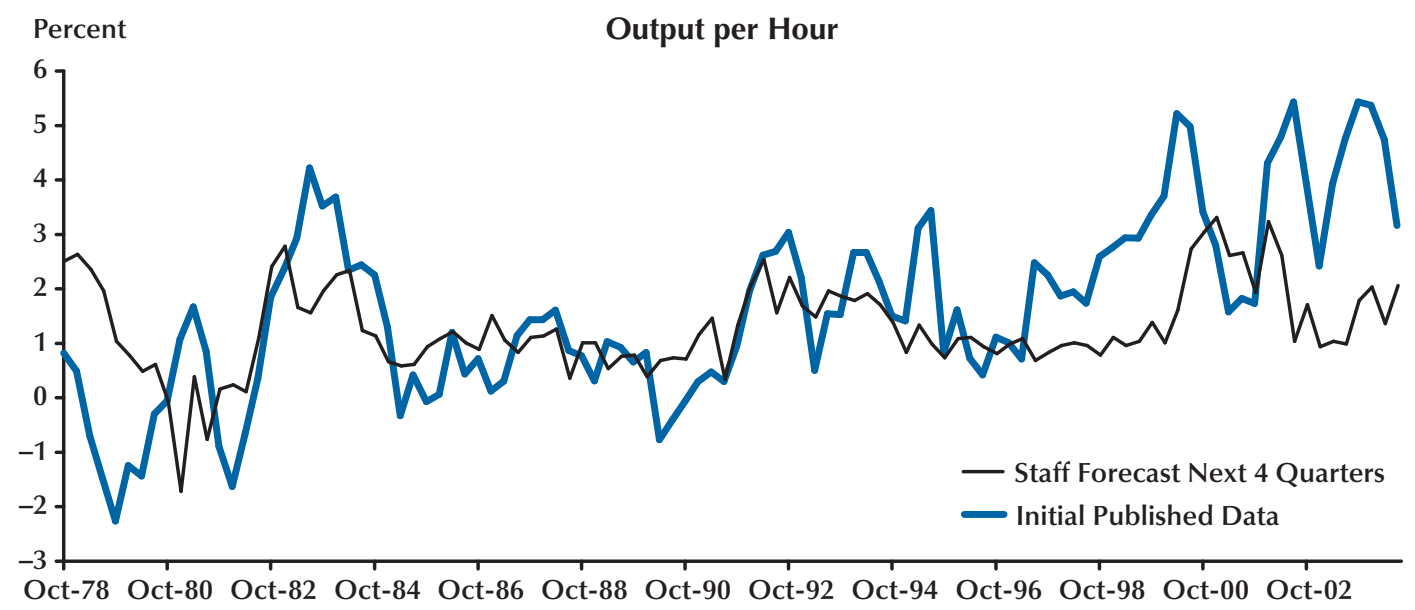

End Date of Forecast Interval

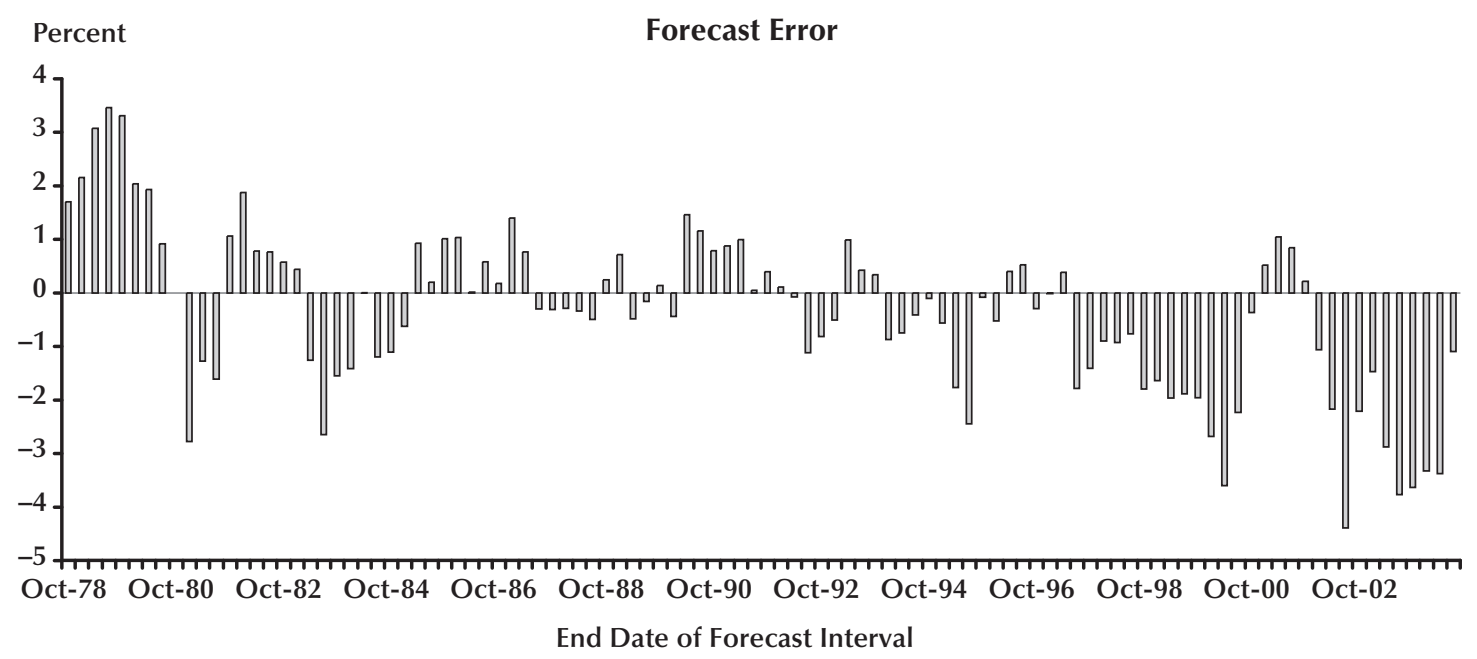

NOTE: The figure examines the accuracy of staff forecasts of the change in productivity during a four-quarter period that begins with the quarter in which an FOMC meeting occurred. The measure is calculated as follows: The BLS publishes labor productivity data eight times each year; we use the four issues that contain quarterly initial (first-time published) measurements. The figure compares the staff forecasts with the initial data subsequently published by the BLS. The last forecast shown is for the period ending 2004:Q3. 


\section{Figure $1 \mathrm{~B}$}

\section{Labor Productivity, Nonfarm Business Sector: Initial Published Data and Forecast Error (Increase During the Previous Quarter, Percent Annual Rate, Quarterly)}
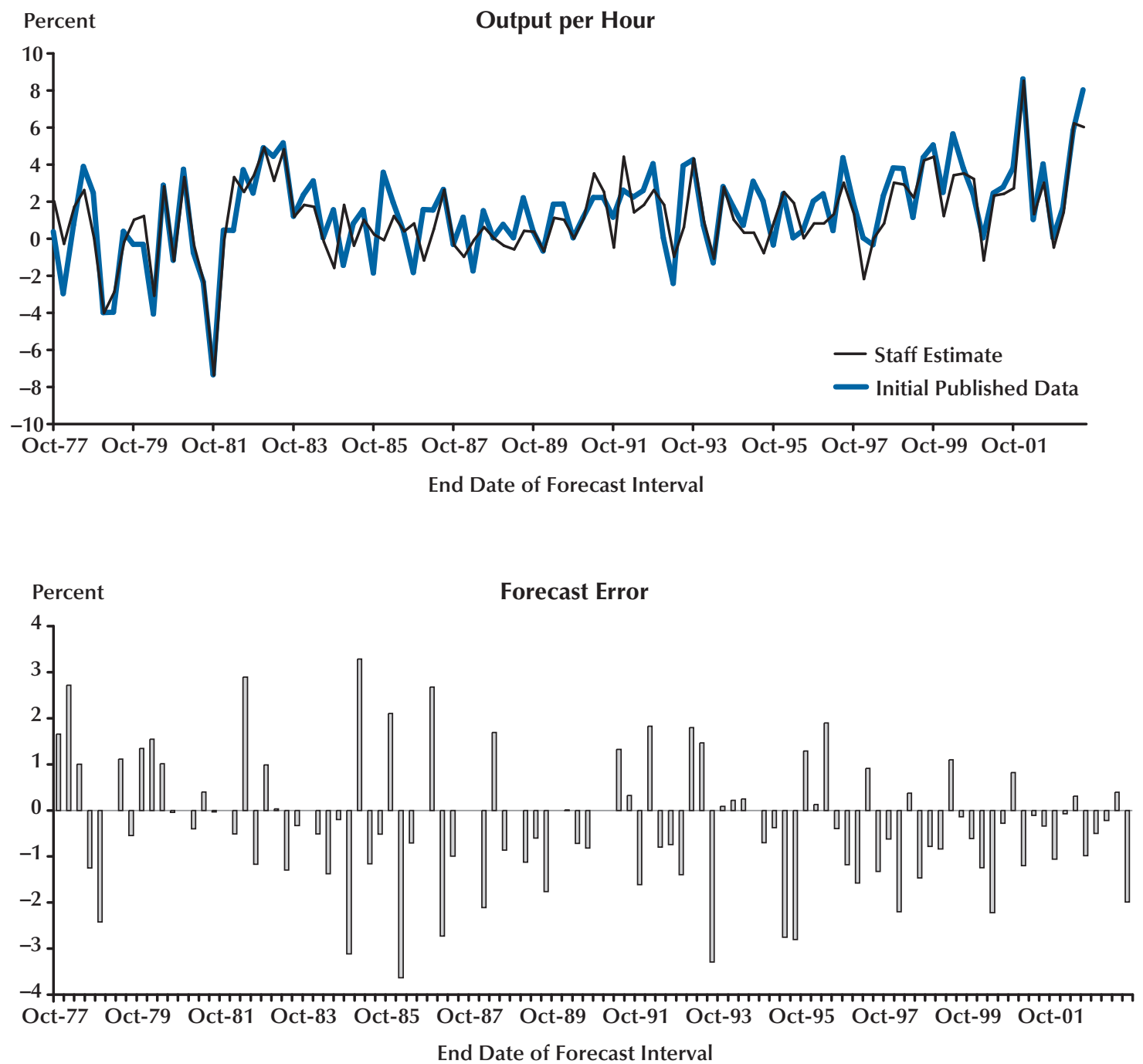

NOTE: The figure examines the accuracy of staff estimates of the productivity growth that occurred during the quarter immediately preceding the quarter in which the FOMC meeting occurred and before publication of an estimate for that quarter by the BLS. Our measure is calculated as follows: The BLS publishes labor productivity data eight times each year; we use the four issues that contain quarterly initial (first-time published) measurements. The figure compares the staff estimates with the initial data subsequently published by the BLS. The last estimate shown is for 2003:Q3. 
Figure 2A

Real GDP Growth: FOMC Staff Forecast, Initial Published Data, and Forecast Error (Average Growth During the Next Four Quarters, Percent Annual Rate, Quarterly)
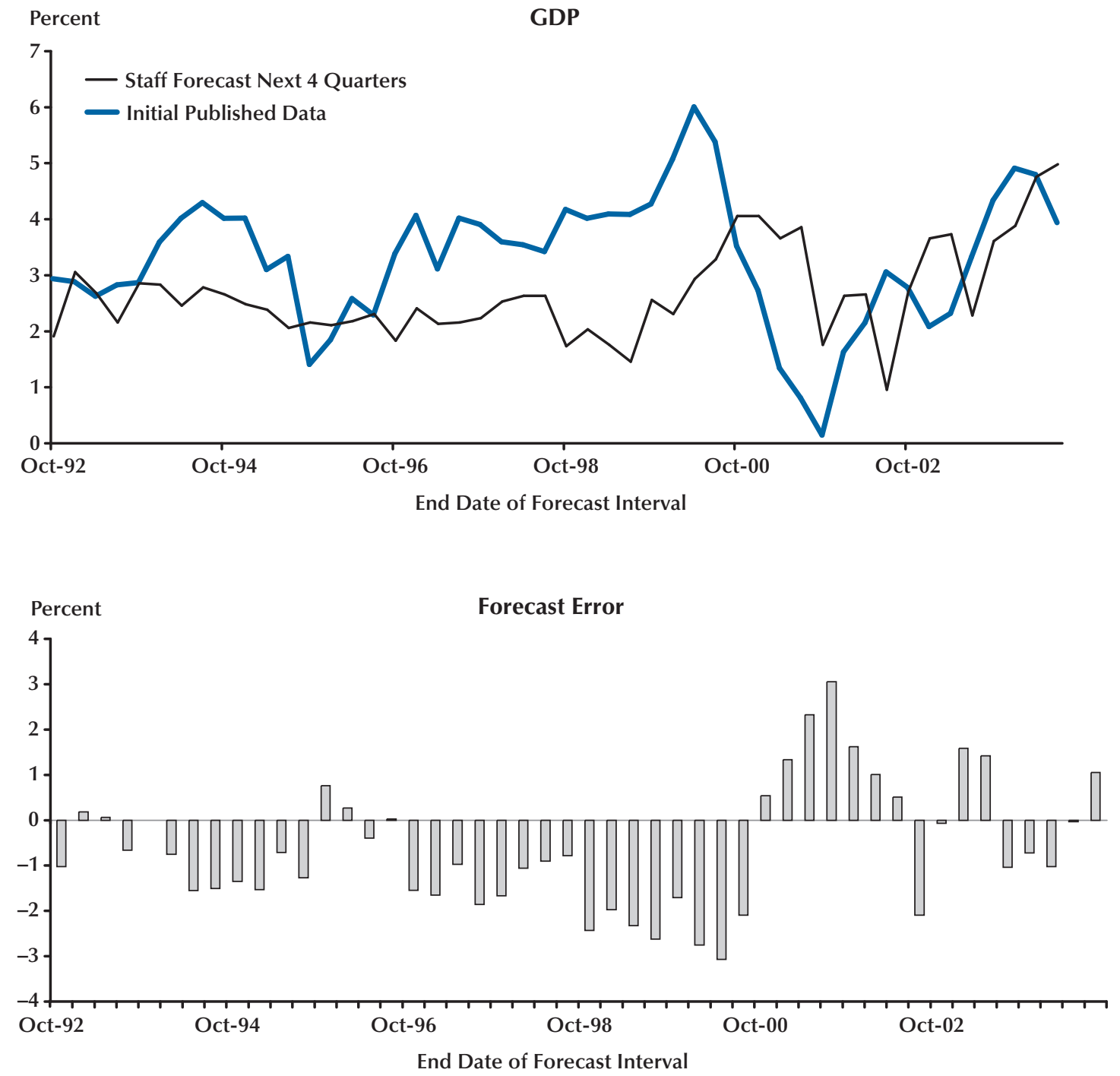

NOTE: The figure examines the accuracy of staff forecasts of real GDP growth during a four-quarter period that begins with the quarter in which an FOMC meeting occurred. Our measure is calculated as follows: The Bureau of Economic Analysis (BEA) publishes real GDP data 12 times each year; we use the 4 quarterly initial ("advance") estimates. The figure compares the staff forecasts with the initial data subsequently published by the BEA. The last forecast shown is for the period ending 2004:Q3. 


\section{Figure 2B}

\section{Real GDP Growth: FOMC Staff Forecast, Initial Published Data, and Forecast Error (Growth During the Previous Quarter, Percent Annual Rate, Quarterly)}
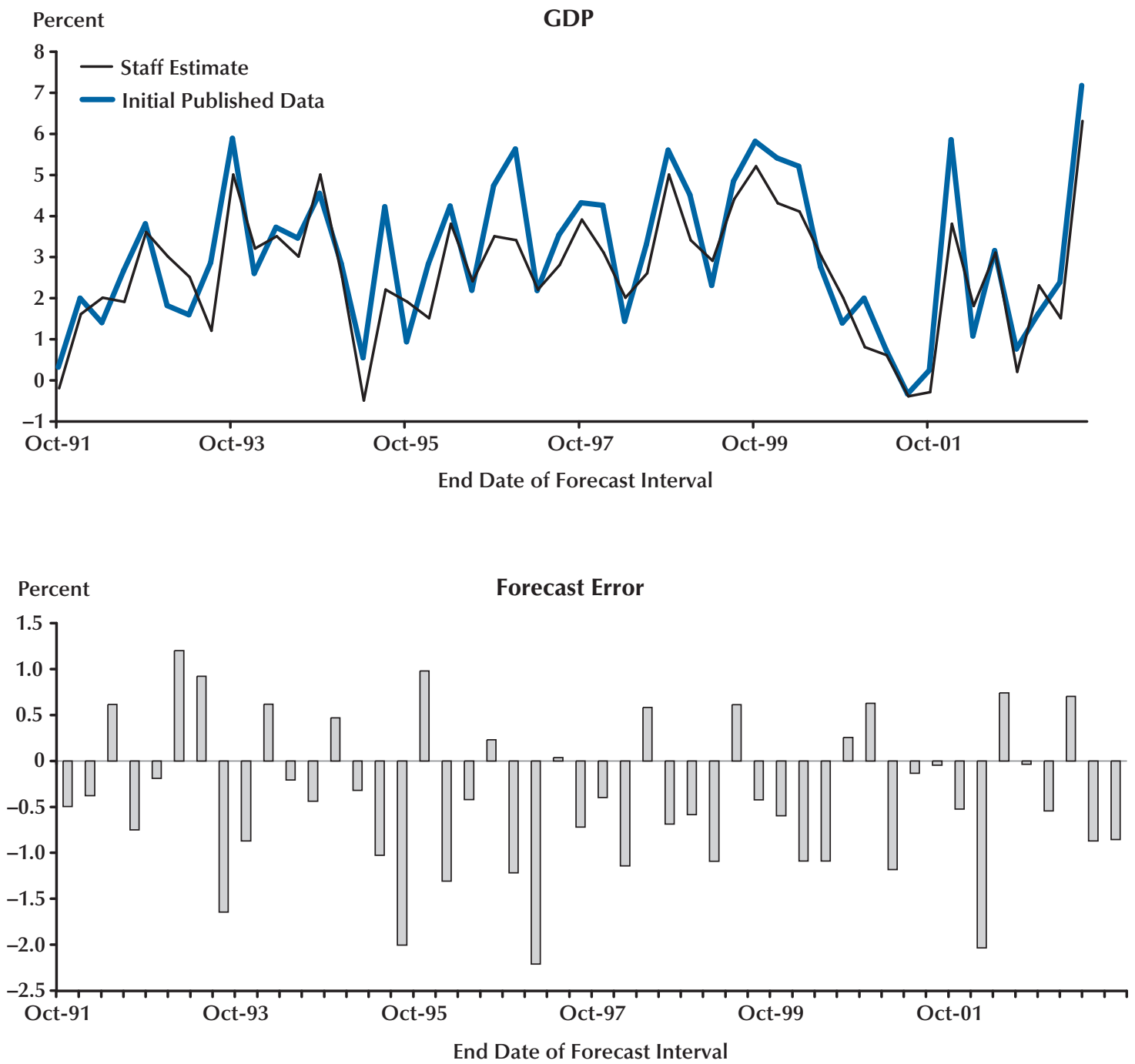

NOTE: The figure examines the accuracy of staff estimates of the real GDP growth that occurred during the quarter immediately preceding the quarter in which the FOMC meeting occurred and before publication of an estimate by the Bureau of Economic Analysis (BEA). Our measure is calculated as follows: The BEA publishes real GDP data 12 times each year; we use the 4 quarterly initial ("advance") estimates. The figure compares the staff estimates with the initial data subsequently published by the BEA. The last estimate shown is for 2003:Q3. 
Figure 3A

Real GNP Growth: FOMC Staff Forecast, Initial Published Data, and Forecast Error (Growth During the Next Quarter, Percent Annual Rate, Quarterly)
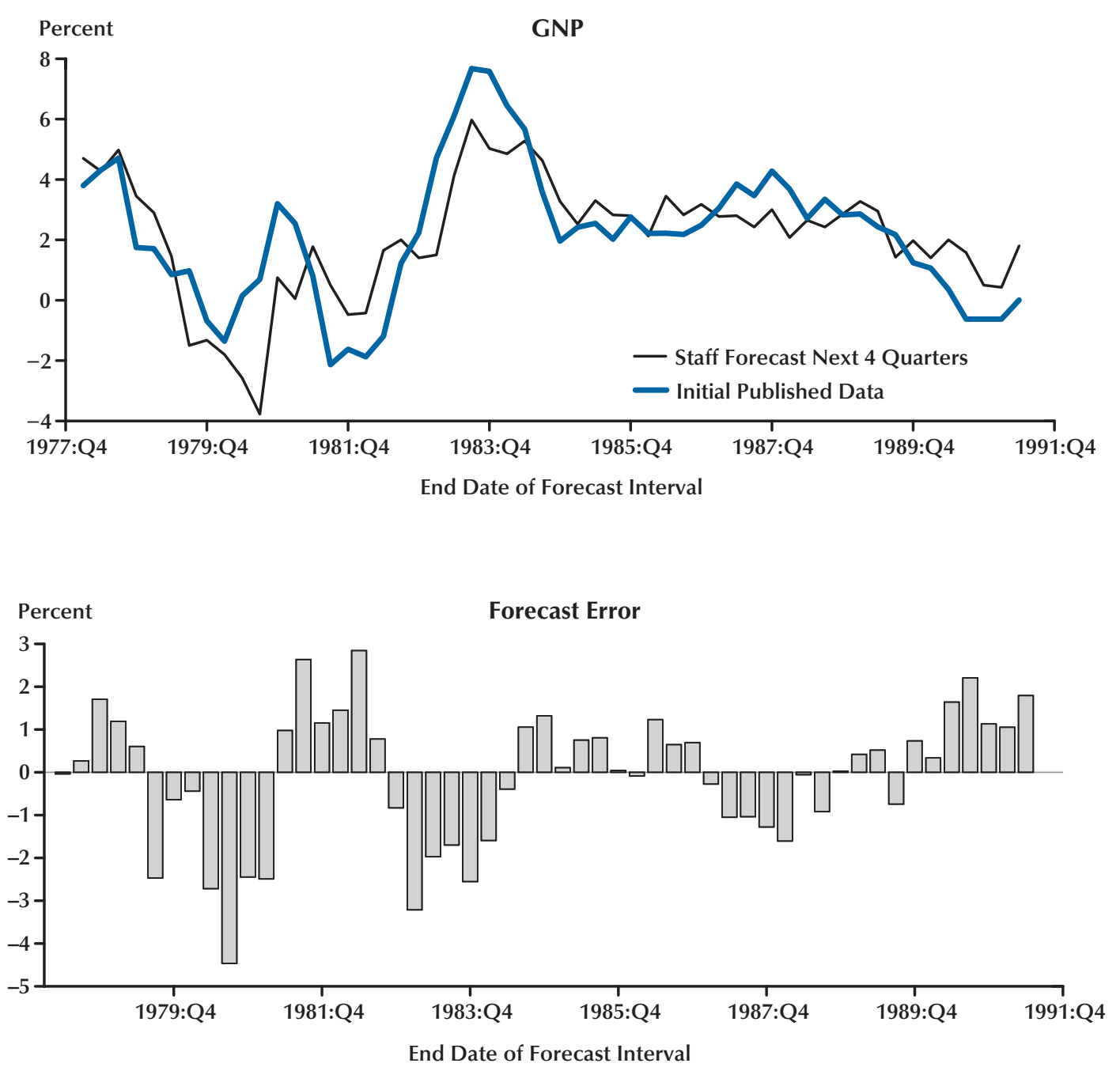


\section{Figure 3B}

Real GNP Growth: FOMC Staff Forecast, Initial Published Data, and Forecast Error (Growth During the Next Quarter, Percent Annual Rate, Quarterly)
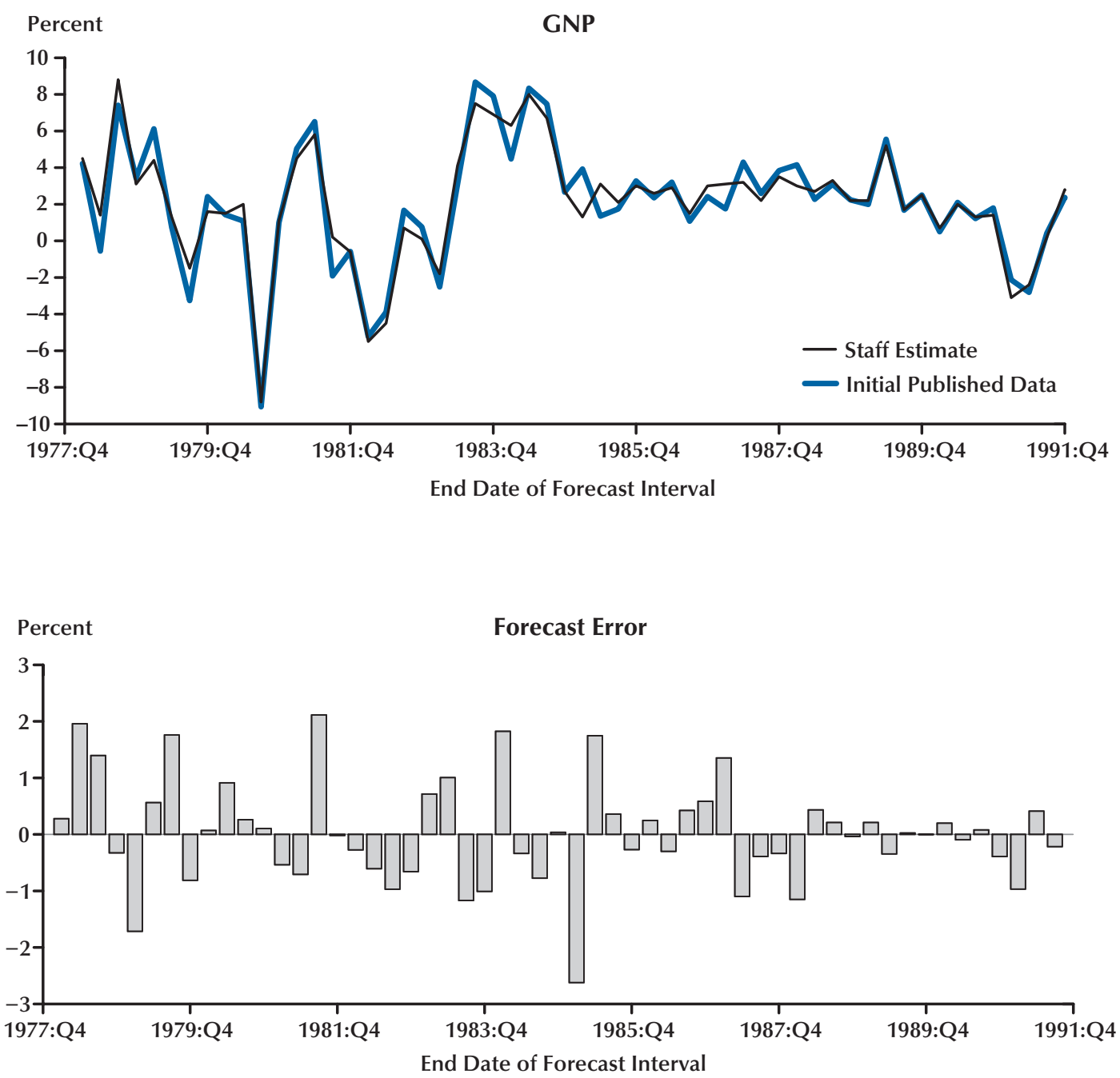


\section{Anderson and Kliesen}

the service sector is stronger than we're measuring then that means, of course, that our economy is doing a little better than we are measuring. So there are those two aspects that are very interesting.

Chairman Volcker teased, "You don't think more computers mean less productivity?" to which Governor Angell responded, "No.” Pressing further at the December 1986 meeting, Governor Angell asked, "How much different does productivity look if you differentiate between the service sector and the goods producing sector?"- - to which the staff answered:

Well, we don't really have good data, as you know, for well over a year. The evidence that we have suggests that manufacturing productivity is probably rising $3^{1 / 2}$ to 4 percent. Service sector productivity is just really quite poor. So, we are getting strong productivity gains: that is important in this forecast. In terms of potential growth, we are trying to look at trend productivity for the economy in total, but there is a great deal of variation among sectors.

Governor Angell followed up:

Then it is possible that we really don't measure productivity in the service sector and don't measure the value of output in the service sector. We just assume productivity is going to be zero in the service sector, and lo and behold it is.

But the staff disagreed: "No, I think there is a little more information than that. Let's say it is open to question but there is a little more information than an assumption of zero." Such discussions continued throughout the 1980s. As the decade closed, at the November 1989 meeting, the staff's projected trend labor productivity growth was little changed from that of the previous decade: $1^{1 / 4}$ percent. In fairness, data available in early 2010 vindicate the staff: Labor productivity growth in the nonfarm business sector averaged 1.4 percent per year during the decade.

\section{THE 1990s}

The FOMC's views on productivity changed during the 1990s, albeit slowly.

\section{2}

The transcripts during the recession of 1990-91 contain little discussion of productivity. When discussion resumed in 1992, the staff projected trend labor productivity growth at the same pace as that of the prior decade. Transcripts for the first half of 1992 contain no new analysis of productivity. At the August meeting, for example, the projected rate was a 1 percent pace, similar to the 1980s. Both President Gary H. Stern (Minneapolis Fed) and Chairman Greenspan questioned the degree of uncertainty in that figure. The Chairman asked: "Is there a tendency that that 1 percent might be higher?" The staff, in reply, argued that their caution during the 1980s, when they refused to increase their projection, later was confirmed by the data:

\section{If one thinks back to where we were in the early '80s, coming out of that recession there was a tendency, I think, for many people to overesti- mate the improvement in productivity. There was talk then that the trend had improved to maybe 2 percent or in excess of 2 percent and it turned out to be a disappointment that as we progressed through the decade we didn't see that kind of improvement. I think it's always difficult when you see the good increases in productivity early on [in a recovery] to know exactly how much is trend and how much is cyclical.}

At the December meeting, the Chairman noted that the early 1990s had been a "productivitydriven recovery" with little increase in hours worked, "unprecedented in the context of how little economic growth we have had since March 1991." He offered two explanations. The first he regarded as of lesser importance-output was unprecedentedly low, relative to available inputs of capital and labor, at the business cycle trough. The second, he argued, was essential: Improvements in software development were allowing businesses to rapidly reengineer business processes, with resulting increased long-term productivity growth. For years, he argued, major inputs of increasingly powerful ICT hardware generated little gain because software engineering lagged. Now, gains in output per work hour were being seen in both the manufacturing and nonmanu- 
facturing sectors. Allowing for a lag of 5 years or longer for development of idiosyncratic systems, Greenspan's argument was consistent with the history of modern computer networking. ${ }^{5}$

\section{3}

Discussion continued at the February meeting. Members noted the 3 percent increase in labor productivity in 1992 and asked why the staff projected a 1.3 percent pace during 1993. The staff noted the 1.3 percent pace was an increase from their previous projection of 1 percent. At the March meeting, the Chairman noted: "Productivity is picking up in a fairly substantial way, and I suspect it is basically real." At the August meeting, Governor Angell emphasized the discordance in the data:

Productivity has been a real puzzle for me. Clearly, if your forecast gets really thrown awry you say it's a puzzle; and part of my real economic forecast for [1993] has certainly missed the mark. I really just don't understand productivity. I don't understand how we can have a decline in productivity for the business sector of $1^{1 / 2}$ and $2^{1 / 2}$ percent two quarters in a row when productivity in manufacturing has been rising at $4 \frac{1}{2}$ to 5 percent!

At the following meeting, he noted that revisions to the national income accounts had worsened the puzzle: "To make it even worse, the revisions seem to show productivity trends higher than we thought they were. We've got productivity trends [that are] very, very high." The Chairman noted: "The more I look at the data the more I'm inclined to believe, as some of you have hinted, that there is something wrong with the numbers we are looking at. It's just not credible to me that we can have a significant rise in employment and in hours both from the payroll series and the household series-two measures that are about

\footnotetext{
5 The Software Engineering Institute at Carnegie-Mellon was established in 1984 to advance software engineering standards and practices. Also in 1984, the University of California at Berkeley released version 4.2 of BSD Unix, which included a complete TCP/IP (transmission control protocol/Internet protocol) networking implementation. Novell's NetWare was released in various versions between 1983 and 1986 using IPX (internetwork packet exchange) and TCP/IP protocols. In late 1994, Microsoft released its own 32-bit network solution for certain versions of Windows 3.11 .
}

as independent as one can get of an economic phenomenon-and say that the GDP indicates productivity declined in the first half of this year."

\section{4-1995}

Both the data and the Committee's discussions proceeded, meeting by meeting, largely in the same fashion as the previous years. In our judgment, little is gained by a detailed review except for the meeting in December 1995, which has been cited by a number of authors including Blinder and Reis (2005). The Chairman offered "a broad hypothesis about where the economy is going over the longer term and what the underlying forces are." He argued that anecdotal evidence from industry-level sources demonstrated that purchases of equipment and software were changing business in permanent, fundamental ways but poor data quality made the change difficult to observe: "One would certainly assume that we would see this in the productivity data, but it is difficult to find it there. In my judgment there are several reasons, the most important of which is that the data are lousy." Further, he argued, such shifts are infrequent: "The underlying technology changes that support this hypothesis really appear only once every century, or 50 years, or something like that as best I can judge.” Inflation was restrained because technological change had increased job insecurity and eroded human capital, causing both unusually restrained wage increases in the tight labor market relative to the historical record and a desire by workers for longer-term contracts (5 to 6 years). Furthermore, advances in ICT had reduced infrastructure and back-office costs, including communications and transport costs per unit of value added. He emphasized his continuing skepticism regarding productivity statistics and reiterated that businesses and industries must reorganize-often a slow process—to take full advantage of major technological innovations. With respect to monetary policy, he noted: "It is unclear exactly how [the reorganization] fits into our policy process. But I think it is important to put this point on the table, and I present it as a hypothesis since it is something that we will not be sure is the appropriate assessment of our changing world for probably five to ten 
years." To bolster further his argument that actual productivity gains were greater than those in published data, the Chairman cited rapidly increasing profits. ${ }^{6}$

Former Federal Reserve Governor Laurence H. Meyer (2004) noted that the Chairman's views on the productivity acceleration were informed primarily by contacts in the business sector. Data available through the late 1990s, for example, suggested that the services-producing sector had achieved no productivity gains in 20 years-an unlikely event.

\section{6}

The most important information presented to the Committee during 1996 was a productivity study conducted at the Chairman's behest by two Board staff members, Carol Corrado and Larry Slifman (1999). A number of authors have noted that, by 1996, the Chairman had been questioning the Bureau of Labor Statistics (BLS) official productivity figures for three years (e.g., see Woodward, 2000, pp. 171-74). Of particular concern were services-producing sectors, where little or no measured productivity gain had been found in the past two decades. Suspicion fell primarily on incorrect price indices for the sectors' outputs because mismeasurement would impose a downward bias on measured real output. The CorradoSlifman study concluded that the data did not support a productivity acceleration, but that it was unlikely actual productivity in unincorporated services-producing businesses had decreased during the past two decades by approximately a half percent per year, despite published measured productivity so doing. Woodward (2000, p. 174) writes that "Greenspan was delighted."

6 The indicator value of increasing profits as a signal of increased productivity has a long history; see, for example, comments by Edward Boehne during the February 1983 FOMC meeting. The Board staff's productivity trend rate, as of February 1983, was approximately 1 percent, versus $2^{1 / 2}$ percent earlier in the postwar period. The Board staff was forecasting actual productivity growth of $2 \frac{1}{2}$ percent in 1983 and $1 \frac{1}{2}$ percent in 1984, driven by manufacturing, with not as much going on in the services sector. In the FOMC transcripts, Board research director Kichline notes that some interesting things happened in 1982. One is that productivity started rising very early.
1997

Throughout the year, Committee members brought to the table numerous anecdotes regarding firms pursuing capital investment to increase productivity rather than expand capacity. Staff projections for trend productivity remained modest at approximately a 1 percent annual pace, decreasing somewhat late in the year based on staff judgment that strong actual productivity growth at rates near $2^{1 / 2}$ to 3 percent was "a spurt."

At the February meeting, the staff estimated that productivity during the fourth quarter had increased at a $2 \frac{1}{2}$ percent pace, and yet reduced the projection of trend productivity growth to 0.9 percent from an "optimistic" 1.1 percent. Governor Alice Rivlin noted: "The productivity data remain significantly mysterious; the low increases do not seem to fit with other indicators." The Chairman responded bluntly to suggestions that productivity growth had not picked up: "So, the productivity gains implicit in these data [the anecdotal reports] are larger than the ones we are getting in the official data. The one thing we know about the official data on productivity is that they are wrong."

At the March meeting, the Chairman noted that "productivity is badly underestimated and indeed may actually be accelerating." He argued that productivity in the nonfinancial corporate sector must be increasing at approximately the same rate as wages because unit labor costs were not increasing and corporate profitability was robust. At the May meeting, the staff increased their projected trend productivity growth to a 1.2 percent pace and suggested that the recent productivity acceleration was little more than might be expected with a "surge in aggregate demand." The Chairman noted that average hourly compensation data suggested productivity growth of approximately 3 percent between the first quarters of 1996 and 1997-but the data suggested a longterm decrease in productivity in the noncorporate business sector that "makes no sense.

At the July meeting, senior staff discussed the tendency for productivity gains to induce increases in aggregate demand (both producers' durable equipment and household spending) that outstrip increases in supply: "There is a bigger 
effect in our models in terms of investment demand and consumer spending that actually causes the net effect of this improvement in productivity to be expansionary for the economy." The meetings during the balance of the year continued these same themes. Few new issues arose.

\section{8}

The year 1998 was pivotal. As the economic expansion strengthened, the Committee focused on the role of the productivity acceleration in forestalling higher inflation. ${ }^{7}$ At the February meeting, published data showed a sharp increase in productivity growth: Productivity in the nonfinancial corporate sector had grown at a 2.1 percent pace during the fourth quarter and increased 3.2 percent from 1996:Q4 to 1997:Q4, a full percentage point higher than during the comparable yearearlier period. Yet, the staff was projecting slower productivity growth during 1998, followed by a modest rebound in 1999. Members noted that, during the previous year, the staff had estimated the trend growth rate of productivity at $1 / 4$ of a percentage point; if correct, this slow increase, in the views of some members, portended higher inflation. ${ }^{8}$ The staff assuaged fears by arguing that the projected growth of output was less than the growth of potential output and an increasing flow of cheap imports would further temper inflationary pressures.

The February meeting was noteworthy for a rare candid discussion of the dynamic linkages, as viewed by senior staff, among labor demand, wages, and labor productivity. The Chairman asked: "How significant is the correlation between nominal compensation and productivity?" The staff responded that the rate of wage increase may be regarded as predetermined [if not exogenous] during the period for which the Committee wished

\footnotetext{
7 The unemployment rate for the civilian noninstitutional population, as measured by the household survey, had peaked in 1992 at 7.5 percent. By 1997, it had fallen to 4.9 percent, most recently achieved in 1973 as the "Great Inflation" was beginning. In 1998, unemployment averaged 4.5 percent; in 1999, 4.2 percent; and at its cyclical low in 2000, 4.0 percent.

8 Currently published figures, as of this writing, are 2.7 percent for 1997:Q4 and 3.0 percent 1996:Q4-1997:Q4 (versus 3.9 percent 1995:Q4-1996:Q4).
}

to discuss the path of inflation: "The correlation is very weak in the short run and the lags are so long that the largest compensation increases tend to occur when productivity increases are beginning to fall near the end of a cyclical expansion." Another staff member explained that, in a regression, nonfarm business productivity is not a significant factor in explaining nominal wage gains: "We know that real wage aspirations, loosely based on productivity, ought to be an important factor in conditioning wage demands, but businesses may not be willing to grant the wage increases. To the extent that fluctuations in productivity do not show up in wages, the first round effects will show through to profit margins rather than nominal compensation." The Chairman suggested that both workers and employers might be more forward looking than the staff described, negotiating labor contracts consistent with expected productivity growth. Furthermore, he suggested the likelihood of an endogenous component to productivity growth itself: "[W]hen nominal wages are beginning to accelerate, then business escalates its efforts to reduce costs and improve productivity. So, if that model were functioning in a meaningful sense, then a significant rise in nominal wages could very well merely reflect the fact that productivity was rising and therefore unit labor costs were not." Senior staff members cautioned that the long-run impact of more-rapid productivity growth on inflation was likely small. They noted that in model simulations where productivity growth increases by 1 percentage point and is sustained at that pace for a decade, "The simulations provide the cautionary note that these favorable effects on inflation are temporary... inflation will begin to pick up if unemployment is held at that lower rate, even if the trend in productivity is tilted up permanently." In the simulations, more-rapid productivity growth only briefly attenuates inflation: Within a year, the path of unit labor cost is unchanged as nominal compensation growth rises to reflect the higher productivity growth.

The staff also outlined a second mechanism in which more-rapid productivity growth increases rather than decreases inflationary pressures: "A faster trend for productivity increases demand 
substantially, as the accelerator effects associated with attempts to keep capital growing in pace with the more-rapid growth in output cause investment to jump, and as consumption rises with permanent income. However, supply only picks up gradually, in line with faster productivity growth."

The March meeting began with the staff acknowledging that their previous real GDP growth forecast was too low. Yet, the staff forecasted first-quarter real GDP to grow at a 3.1 percent pace and labor productivity to decrease at a -2.2 percent pace. The staff argued that such a drop was not "implausible" given the increase in labor productivity during the previous two years relative to the staff's underlying trend: "If we have it right, a movement back toward the trend line was to be expected over time-and, given the erratic character of the series, a substantial drop in some quarter would be far from shocking." Committee members agreed that extreme uncertainty surrounds both the near-term increase and long-run trend in productivity. Several members noted that the staff's combined labor market and productivity projections implied sharp increases in unit labor costs and, given the Committee's markup-pricing analytical framework, higher inflation: 3 percent rates in the core CPI and core personal consumption expenditures (PCE) price indices. The staff counseled caution because other "special factors" were constraining inflation:

It was supply uncertainties—questions about whether the economy might be able to sustain faster expansion through faster productivity growth and a higher level of resource utilization than suggested by history-that deterred the Committee from tightening last fall, and those uncertainties have not been resolved. Despite a low unemployment rate and anecdotes of strains in labor markets, wage and compensation inflation still seems to be moving up only slowly. Price inflation remains largely quiescent, and a resumption of robust investment spending in the first quarter should keep industrial capacity ample.

The Chairman repeated his skepticism of the productivity data:
The productivity numbers are very rough estimates because we are measuring a whole set of product outputs from one set of data and a whole set of labor inputs from a different set. That they come out even remotely measuring actual labor productivity is open to question... the BLS estimates that output per hour increased at a 6.3 percent annual rate in the third quarter of 1997. It just is not possible for productivity to increase that fast.

At the May meeting, the staff projected slower near-term, but more-rapid longer-term, productivity growth. Responding to data revisions, the staff increased their projection of trend productivity growth to a $1 \frac{1 / 2}{2}$ percent pace. Some members were skeptical: Why should an increase in trend productivity growth reduce trend growth in unit labor costs, when economic theory suggests that long-run increases in wages and productivity move together? The Chairman reemphasized his faith in the productivity acceleration: "The more interesting data provide increasing evidence that the underlying trend of productivity is moving up...It is clear that a very significant acceleration in productivity has occurred compared with the previous trend. A goodly part, perhaps most of it though not all, is attributable to a pickup in the rate of capital deepening. There clearly have been improvements in the quality of labor and because the residual, which we call total factor productivity, has gone up as well."

At the June meeting, the staff's economic outlook echoed the Chairman's comments at the May meeting-labor productivity had accelerated, and the increase was due to capital deepening and improved multifactor productivity. Unit labor costs were projected as unchanged, with wage increases offset by productivity gains; labor compensation, measured by the employment cost index, was projected to increase at a $3^{1 / 2}$ percent rate. At this meeting, the Chairman emphasized that gains in productivity, in certain circumstances, engender increases in inflation, rather than decreases. "[A]s productivity growth has accelerated, expectations about earnings over the long run have moved up. This has created a major increase in stock prices and a virtuous circle wealth effect. We end up with (1) much higher 
domestic demand and (2) lower prices because of the acceleration in productivity that has occurred."

Productivity was little discussed at the remaining meetings of 1998, as the Committee confronted the Russian debt default, the Asian financial crisis, and the rescue of the hedge fund Long-Term Capital Management. At the August meeting, a few members expressed doubt regarding continued strong productivity growth, while the Chairman expressed confidence in continued strong growth. At the December meeting, the staff noted that incoming data on GDP had been fully consistent with the more-rapid trend productivity growth accepted by the staff earlier in the year.

\section{9}

Committee meetings during 1999 contained a wide range of viewpoints. Some members feared inflation based on their historical experience with tight labor markets and Phillips curve models. The staff feared inflation if wealth effects induced by the productivity acceleration caused aggregate demand to expand in advance of aggregate supply. The Chairman pressed forward his argument that the economy was benefiting from a technology shock on a scale not experienced since the nineteenth century.

At the February meeting, the Chairman noted that productivity increased during the third and fourth quarters at 4.7 and 4.8 percent annual rates, respectively, and that unit labor costs for nonfinancial corporations had increased over the four quarters of 1998 just 0.2 percent, with compensation per hour increasing 4.0 percent and productivity 3.8 percent. The staff, however, saw the productivity acceleration as sowing the seeds of their own demise. Productivity gains, they argued, were strengthening aggregate demand, especially for producers' durable goods, more rapidly than increasing aggregate supply: "Greater capital spending does raise the productivity of labor and the level of potential output over time, but its more significant effect in the short run is on demand. Thus, policy must be appreciably firmer if demand surprises on the upside, even if it is productivity-enhancing spending that constitutes the surprise" [italics added]. The Chairman argued that staff projections of rising inflation were wrong because the economy had experienced a "fundamental" change. He discarded his previous rationale for low inflation-workers' fear of job obsolescence, layoffs, and outsourcing:

How is it possible, first, for hourly compensation growth to be flat or falling in an evertightening labor market? Let me begin by suggesting what does not explain it. You may recall that two or three years ago I was arguing that fear of job obsolescence was a major factor suppressing the nominal increase in compensation per hour. That factor clearly has not gotten worse; if anything, it has eased...[A]n increase in uncertainty and the fear of job loss amongst workers cannot account for this extraordinary combination of low unemployment and no acceleration in hourly compensation.

He cited globalization and its increased competition as denying pricing power to business:

The argument is basically that tradable goods prices are being significantly held down by excess world capacity and that the arbitraging into the nontradable goods areas that occurs within economies, largely through wages, is the reason why service price inflation, which arguably has very little in the way of direct international globalization components, also has been restrained appreciably. In the United States this process has been augmented by a dramatic increase in the backlog of new technologies.

Moreover, he argued, it was unlikely that increases in aggregate demand would exceed gains in aggregate supply because employers would offset cost pressures through capital investment:

[T] he synergies that have evolved over recent years have created a large pool of potential capital investments that firms can dip into to obtain a rate of return in excess of the cost of capital. We have seen considerable evidence of this in the sense that rates of return everywhere seem to be moving up.

...[W]e are getting a rapid increase in opportunities for investment in new technology. It is overwhelming the expansion of demand, and the acceleration in the downward adjustment of prices suggests that we have a very large 
backlog of unexploited investments that, as they are implemented, are displacing labor and effectuating a very significant increase in multifactor productivity. That in turn has spilled over into labor productivity.

...[I]t is evident that whenever nominal wage pressures have surfaced, producers have chosen to dip into the available technology to substitute profitable capital for labor. This has made the growth of potential output per hour variable; indeed, it's a function of nominal wage increases. The reason is that if nominal wage increases pick up, there is clear evidence in recent years that producers will endeavor to dip into that untapped pool of technological capital projects.

At the March meeting, the staff increased their estimate of trend productivity growth to a 1.9 percent pace and foresaw little inflationary pressure. Committee members expressed concern that the more-rapid productivity growth would not continue. The Chairman noted that repeated staff projections of slower economic growth and more-rapid inflation had been incorrect. He noted that the combination of a slower rate of increase in compensation per hour and accelerated productivity had lowered the growth in unit labor costs for the nonfinancial corporate area to 0.1 percent over the past four quarters. He emphasized again that measurement error plagued published productivity data, particularly the noncorporate business sector where published data suggested that "measured annual productivity had declined about 2 percent per annum on average since the late 1970s. That is just not credible."

The discussion of inflation intensified at the May meeting: The primary question was, with a 4 percent unemployment rate, is monetary policy consistent with stable inflation? Output grew at a 4 percent pace during the previous four quarters, with strong productivity gains and decreases in broad measures of nominal wage and price increases. Yet, the staff argued that projected productivity growth was inadequate to sustain longrun outcomes of 4 percent unemployment and near-constant inflation: Price inflation would increase unless domestic demand softened.
President Robert T. Parry (San Francisco Fed), seeking a measure of the uncertainty of the productivity forecast, was representative of the concerns: "Estimates of the productivity trend seem to have been revised quite frequently in the last few years. To me, this suggests greater uncertainty about the productivity forecast. Wouldn't you have to conclude that the uncertainties associated with our forecast of real output and inflation must be greater given the uncertainties that are associated with the productivity forecast?" Governor Meyer, however, accepted a shift in trend but argued that the staff likely had gone too far with their increases in the trend rate:

The case for an increase in trend productivity growth is now more compelling after the strength in productivity over the last five quarters-and especially after the last two quarters-than it was based on the data for 1996 and 1997. And I believe the staff's pattern of incremental upward steps in trend productivity growth makes sense, with some acceleration in productivity beginning in late 1995 and a further acceleration in 1998. My problem with the staff forecast is that its projection of a $2 \frac{1}{4}$ percent productivity trend over the forecast period [the following 8 quarters] is just too aggressive for my taste.

The Chairman acknowledged the risks of his preferred policy: "[T]he interesting issue is why wages are not rising faster if productivity is doing what all the evidence suggests it is doing. We have a unique anomaly. Credulity gets strained more and more the longer it goes on. It is hard to avoid the conclusion that there is an increasing imbalance here that we have to address."

At the June meeting, the staff projected trend productivity growth at a $2 \frac{1 / 4}{4}$ percent pace, more rapid than other forecasters. (The Council of Economic Advisers, for example, projected a 1.6 percent rate.) At the August meeting, the staff's model simulations suggested that if productivity growth slowed and labor markets remained tight, inflation would accelerate. The Chairman saw no slowing of productivity growth:

I find no evidence yet that the increase in the rate of growth of productivity has slowed at all. To be sure, the official published data for the 
second quarter, which showed productivity growth of 1.3 percent and will be revised to below 1 percent, would suggest a very significant slowing. The problem is that about 2 percentage points of that number reflects the change in the statistical discrepancy. And that published second quarter number is not in any way consistent with what we know is going on out in the real world.

...The figures in the data that we are looking at from the income side show productivity growth over the four quarters ending in the second quarter of around $3^{1 / 2}$ percent.

...Where is the inflation? It is not showing up anywhere in the basic price data. And the people out in the business world with whom I talk, and it's a fairly extensive group, keep complaining about their inability to raise prices. I do think that wages will continue to increase if productivity growth continues to rise. But since this would mean that unit labor costs would be little changed, that won't be a source of price pressures.

...Inflation is clearly prone to acceleration should the increase in the growth of productivity slow or even stabilize. That hasn't happened yet as far as I can tell.

The Committee increased its target for the federal funds rate by 25 basis points.

At the October meeting, some members pressed for further increases in the federal funds target. The staff forecast called for slowing productivity growth and increasing inflation. The Chairman asked whether the staff model's foundations were adequately dynamic to capture the extraordinary supply-side changes that he recognized, noting that correct policy action hinged on one's judgment regarding the magnitude (and sign) of a "second derivative." He suggested that the staff models inadequately captured interactions between the demand and supply sides of the macroeconomy:

I see as growing evidence that the models with which we have been trying to explain how the American economy functions are becoming increasingly obsolete. It is not that the econometric structure of the models is inappropriate, but certain simple assumptions are made in their structure that are driving the results we observe and are creating at least the presumption that we are missing something important. ${ }^{9}$

He asserted that the "second derivative" of productivity had been positive since 1995; that is, the longer-run trend growth rate of productivity had continued to increase.

October's discussion continued at the November meeting, as Committee members asked how long the Chairman's second derivative could remain positive before returning to its "traditional" value of zero. Members almost uniformly reported robust productivity gains in their Districts, and the staff increased their projected productivity growth rate by several tenths of a percent, in part due to revisions to national income accounts data. ${ }^{10}$ The Chairman asked members to "follow his lead." Although incoming data supported his view, he conceded that productivity accelerations create "unbalanced" expansions that cannot continue. He cautioned the Committee that neither the large current account deficit nor the expanding employment of marginal workers could continue unchecked: Eventually, the imbalance between aggregate demand and supply would be resolved through increases in long-term real interest rates. "The trouble," he notes, "is that the lags are invariably quite long, and we do not know how much rate tightening [in monetary policy] is required to bring supply and demand into balance."

The year's final meeting, on December 21, was quiet. No significant new analysis was presented. The Chairman repeated his belief that increases in the growth rate of productivity-a positive second derivative-could not continue indefinitely. But few price pressures were noted, and the Committee agreed that a policy action would be unwise on the eve of the century date change.

\section{0}

The Committee during 2000 came to regard further increases in productivity growth as

9 The Chairman's comments describing inadequate attention to supply-side technology shocks echo, perhaps unintentionally, those of Nobel laureate Edward Prescott.

${ }^{10}$ For discussions of productivity revisions and the national income account revisions, see Anderson and Kliesen (2006). 
unwelcome, lest stronger aggregate demand place upward pressure on inflation. (Ironically, the following year, the Committee came to regard further increases as a potential cause of unwelcome disinflation or, worse, deflation.)

The year began with optimism. At the February meeting, the staff increased their estimate of trend productivity growth to a 3 percent annual rate, double the pace of the 1980s and early 1990s. President Cathy E. Minehan (Boston Fed) noted that the staff's productivity growth projection was more rapid than almost all other forecasters. Governor Meyer defended the forecast, saying, "[T]he main difference is that the staff here has a very strong view of the interaction of supply and demand. This common force of productivity is affecting both demand and supply. I think they have been proven very accurate in that. One doesn't see that perspective in most of the private forecasts." The Chairman agreed and went further: "I think that is exactly right. In fact, the risks to the staff forecast may very well be on the up side. The probability that their forecast is too low is by no means negligible." Inflation concerns were widespread. President Michael H. Moskow (Chicago Fed) cited advice from his academic advisory council; others cited labor market pressure. Governor Edward M. Gramlich, in counterpoint, saw few inflationary pressures, noting that unit labor costs were near constant and that the Blue Chip survey was not forecasting an increase. But Governor Meyer saw inflation: "[My] judgment is based on the still more robust growth at the already very high labor utilization rate, by the dissipation or reversal of the favorable relative price shocks that have been restraining inflation, and by some signs of incipient pressure on nominal compensation and inflation." He explained that the Chairman's virtuous circle had become villainous:

[There is] a growing appreciation of the importance of higher productivity growth in explaining recent macroeconomic experience...the key challenge for monetary policy today derives from the persistent imbalance between the growth in supply and demand...higher trend productivity growth appears to have had simultaneous effects on demand as well as supply via the investment boom to take advantage of profitable opportunities and via the consumption boom driven by the surge in equity values and perhaps expectations of higher permanent income.

He cited staff forecasts wherein " 0.2 percent higher productivity growth results in $1 / 2$ percentage point faster growth in basic demand. That's the problem I think we are facing." In his remarks, the Chairman expressed similar concern: "[I]nflation will stay down because of the acceleration in productivity. But, ultimately, if we do not solve the problem of the gap, meaning that if the acceleration in productivity leads to continued expectations of accelerating earnings per share, the only way to eliminate the wealth effect, which has to be eliminated, is for the market rate used by investors to calculate the present value of expected earnings to rise." He cautioned that "too aggressive" an increase in the federal funds policy target could "crack the [stock] market" and lead to financial instability. He proposed a 25-basis-point increase in the federal funds rate target, despite no evidence of increasing inflation. The Committee agreed in consensus.

At the March meeting, the staff again increased their estimate of trend productivity, by 0.2 percentage points, to 3.2 percent. Most members continued to foresee inflationary pressures. Staff noted that "absent a continuation of the almost astonishing productivity gains of the second half of last year, there is a clear risk that those [inflationary pressures] pressures will mount in coming months." Perhaps surprisingly, no member advanced the argument that investment in ICT capital had permitted businesses to reorganize to profitably employ workers previously too costly to employ, thereby increasing both demand and supply-an argument that had seemingly been popular among the Committee members only shortly beforehand.

Forecasts of higher inflation lent a grim tone to the May meeting. The staff projected a levelingoff of productivity growth at a modest 1.5 percent pace, but the Chairman argued, based on corporate profits, that productivity growth was as much as fourfold faster. Staff noted that inflation was tame: Although energy prices had boosted head- 
line inflation, the chain price index for core PCE (omitting food and energy prices) was projected to increase only 2 percent during 2001 . The staff recommended an aggressive 75-basis-point increase in the federal funds rate target to forestall possible inflation. The Chairman emphasized that inflationary pressures are not visible:

What is remarkable at this stage is not that inflationary forces are picking up... when we look through the configuration of unit costs, the estimate we end up with is that unit costs have fallen over the last six months for nonfinancial corporations, indeed for nonfarm business generally....all of the price acceleration we have seen reflects widening profit margins... there is no evidence at this stage that we are experiencing a real underlying deterioration in inflation of the kind that we typically have seen in the past.

Nevertheless, he recommended a 50-basis-point increase in the federal funds rate target: "[T]he evidence indicates that productivity, indeed perhaps underlying GDP, is still accelerating...there is as yet no compelling evidence that inflationary pressures are easing, I believe it would be a mistake not to stay asymmetric and our press release should reflect such a decision."

At the June meeting, the momentum toward fighting inflation continued. Governor Gramlich cautioned against rapid policy change based on inflation forecasts: "Until now the real economy has been rocketing ahead at a seemingly unsustainable rate and there was at least a whiff in the air that underlying inflation was picking up. Now real growth has slowed, quite quickly in fact, and the signs of acceleration in inflation do not look so strong either." He interpreted the incoming data as suggesting little inflationary pressure:

[T]emporary factors slowed the core inflation rate in 1998 and 1999 and these factors have now reversed, showing up as somewhat higher core inflation in early 2000. Abstracting from this reversal, there has been some but not that much of a rise in core inflation.

....Nobody has mentioned long-term inflation expectations, but they have been remarkably stable, remarkably unresponsive to the oil price increases. In addition, the Treasury nominal/ real interest rate spread looked as if it was increasing last month, but it has moved back down to fairly acceptable levels.

...It is at least possible that the Fed has already done enough tightening and that we can stand back and examine our work.

There are grounds for thinking that we have done enough already. If the long-run core inflation rate is about 2 percent and the long-run real interest rate is around 4 percent-which can be read from either the TIP [sic] [TIPS, Treasury inflation-protected securities] market or inflation-corrected nominal interest ratesthe nominal federal funds rate should be at least 6 percent for a balanced economy. Throw in 50 basis points for leaning against the wind or adjusting for the balance of risks and we are at the present funds rate.

In fact, the business cycle dating committee of the National Bureau of Economic Research (NBER) would announce more than a year later, on November 26, 2001, that a cyclical peak occurred during March 2001, beginning a stubborn recession during which the Committee would reduce its federal funds rate target to 1 percent (on June 25, 2003).

At the August meeting, the staff again increased their projection of productivity growth, largely in response to revised data that suggested productivity growth at a 5 to 6 percent pace. The projected trend growth rate was revised upward to $3^{1 / 2}$ percent. Nevertheless, they predicted increased inflationary pressure due to tight labor markets.

\section{1}

The slowing economic activity of late 2000 became widespread during 2001. The year began with a January 3 conference call triggered by weak incoming economic data. Committee members appeared to regard weakness in productivity growth as primarily cyclical. The Chairman noted: "I think it is important to indicate in our press statement that there is little evidence to date of any deterioration in the long-term advances in technology and the related expansion in produc- 
tivity." He was supported by other Committee members.

Optimism continued at the January 30-31 meeting. The staff projected that multifactor productivity was "still growing rapidly...reflected in a strong expansion of permanent income."

At the May meeting, slower business investment spending caused the staff to reduce projected productivity growth, which also affected the inflation outlook: "The reduced pace of structural productivity also underlies the upward revision that we have made to our inflation forecast. In essence, the increases in nominal compensation that we are projecting imply more price pressure than we had previously forecast. In that regard, the incoming data on wages and prices have just about uniformly been to the high side of our expectations."

At the June meeting, the staff projected slower productivity growth and "upward pressure on price inflation." Core inflation was projected to change little because of the beneficial effects of falling energy prices and increased "slack in labor and product markets."

At the August meeting, revised national income data showed somewhat slower productivity growth than previously believed. Because prior-period inflation numbers were largely unchanged, the staff noted that less of the "outstanding inflation performance of the late 1990s" could be attributed to productivity gains.

No new issues regarding productivity surfaced at the October meeting. At the November meeting, the staff reduced projections of productivity growth to reflect the reallocation by business and government of productive capital into increased security following the September 2001 terrorist attacks. Further, both Committee members and the staff recognized that a productivity deceleration might cause aggregate demand to weaken faster than (or prior to) aggregate supply, causing unwelcome further disinflation. The staff noted, with irony, that many who had spent their careers promoting the virtues of slower inflation now found it necessary to promote more-rapid inflation. The situation was serious, if not precarious: The federal funds rate was at $2 \frac{1}{2}$ percent, the core PCE inflation rate was at $1 \frac{1}{2}$ percent, productivity was increasing, unit labor costs were falling, and economic activity was slowing. Considerable discussion at this meeting related to the mention of productivity in the press release because the Committee wished to acknowledge that (i) nearterm productivity might be reduced by the reallocation of resources toward security efforts but (ii) trend productivity would not be harmed.

Projections of trend productivity growth were further reduced at the December meeting, to near 2 percent for 2001 and 11/2 percent for 2002 (versus $2^{1 / 2}$ percent in 1998 and 1999). When trend productivity was accelerating, the staff emphasized the interaction between aggregate demand and supply. Now, with productivity decelerating, the same analysis caused concern regarding unwelcome disinflation-or even deflation. The Chairman noted that, because the federal funds rate was at a low level, it might be wise to leave the federal funds rate target unchanged for a time.

\section{2}

On November 26, 2001, the NBER's business cycle dating committee announced March 2001 as the cyclical peak in economic activity. (On July 17, 2003, the committee would announce November 2001 as the cyclical trough.) At the FOMC, inflationary concerns were muted during the year as the focus shifted to supporting recovery.

At the January 2002 meeting, the staff projected that the economy was close to a cyclical trough-fourth-quarter GDP growth was near zero. ${ }^{11}$ Trend productivity growth apparently had slowed, but some rebound was predicted in 2003. During the meeting's second day, newly released fourth-quarter GDP data suggested that productivity (measured as output per hour in the nonfarm business sector) had increased at a 3.1 percent pace, more rapidly than anticipated.

\footnotetext{
${ }^{11}$ The meeting opened with presentations regarding the zero bound problem in monetary policy, which arises when a central bank, working with an overnight interest rate as its single policy instrument, finds that the desired setting for that rate is below zero. Nominal interest rates cannot be less than zero (absent a subsidy or partial forgiveness of a debt). If the policy rate is at the zero bound and inflation is falling, then the real policy rate will be increasing; if, in turn, this further attenuates economic activity such that inflation falls further (or becomes negative), a cumulative process might be launched that drives the economy into an extended downward spiral.
} 
The staff noted that stronger productivity growth would provide support for future capital investment and strengthen aggregate demand. Chairman Greenspan noted incongruities among incoming data regarding profits, productivity, and business investment: If the fourth quarter in fact was the cyclical trough, then productivity growth in that quarter should have been quite slow, followed by a rebound as the economy rebounded. Instead, fourth-quarter productivity growth was strong and profits higher than expected. Data incongruities caused productivity growth predictions to seem even more uncertain than usual.

The March meeting focused on the risk that continued strong productivity growth might cause further disinflation, or even deflation. Productivity was estimated to have increased in the fourth quarter at a $5^{1 / 4}$ percent pace. For the first quarter, the staff had increased their forecast to a $5^{3 / 4}$ percent pace. The Chairman, in his remarks, applauded the economy reaching price stability but noted that short rates were "in general" lower than desired. He noted that there had been a clear change in the economy: "My impression is that we are looking at something different. This is a different type of economy. This is a different type of business cycle. We now seem to be at a reasonably good point. We have come to that point in part by good policy judgment and in part by just plain luck."

At the May meeting, the staff acknowledged that productivity gains again had exceeded their projections. The staff noted that these gains in part might be cyclical, amplified by a higher-thanusual uncertainty regarding firms' future demand and sales, and in part likely were structural. But neither staff models nor intuition suggested a clear division. News reports, the staff members noted, suggested that layoffs at various firms had forced remaining staff to work harder, increasing stress and worker discontent; to some extent, such actions would not be sustainable over the long run. The Chairman noted that a slowing pace of business investment might portend slower future productivity growth.

The June meeting opened with three presentations on inflation forecasting. One presentation suggested that the pickup in productivity growth during the mid-1990s, combined with the lagged response of wages, explained most of the unanticipated decrease in inflation. The staff increased their projected trend productivity growth to 2 percent and $2 \frac{1}{2}$ percent, respectively, during 2002 and 2003, close to the pace during the "New Economy" second half of the 1990s. These increased projections raised concern regarding additional unwelcome disinflation. Relative to the 1990s, however, the 2002-03 gain was associated with less business investment demand (capital deepening) and more gains from business reengineering (multifactor productivity), reflecting at least in part the shift in rapid productivity growth from manufacturing (during the 1990s) to the services-producing sector (since 2000). Staff members noted also that recent productivity gains, perhaps more than usual, were reflecting firms' intent to squeeze production increases from existing employees because of uncertainty regarding future sales.

At the August meeting, the Committee noted that newly revised national income accounts data had "largely left intact" historical growth in productivity. At the September meeting, the staff again increased their projection of productivity growth in response to stronger-than-anticipated spending and weaker-than-anticipated hours: "We project an increase in nonfarm business output per hour of about 4 percent in the current quarter-a figure which, if realized, would bring the four-quarter growth in labor productivity to about $5^{1 / 4}$ percent. Unlike the astonishing 7 to 8 percent increases that we saw at the turn of the year, the more recent increases almost certainly are not the result of businesses being surprised by unexpected strength in demand." The Chairman noted the changing forces driving productivity gains:

[B] usiness firms have expended a great deal of effort to increase productivity through various means, including the use of previously unexploited efficiencies...that was a fairly solid argument that could be made earlier this year, but it gets pretty thin this far out into the recovery. What we have is a very substantial multifactor productivity growth because clearly we're not getting very extensive capital deep- 
ening. Something is happening, but it is not evident in the data. It's a data dilemma, but the answer is not that the data are faulty. Margins actually have been flat for the last three quarters. We are getting some price deflation in the corporate sector. Part of the acceleration in productivity is showing up in lower prices rather than in higher profit margins. Nonetheless, the data look pretty solid and fairly impressive, and one wonders why all the corporate managers are so gloomy. They are gloomy largely because they have no pricing power. They see very weak nominal sales, with the prices of many of their products falling abruptly while the growth of their real output is quite significant. Indeed, that's where a goodly part of the productivity gains are coming from.

At the November meeting, the members expressed heightened concern regarding the large output gap and continuing disinflation pressures. The Committee reduced the federal funds rate target to $1 \frac{1 / 4}{4}$ percent.

The year concluded with the meeting of December 10. Once again, productivity had accelerated beyond even the staff's optimistic projections. The staff noted that reported productivity for the third quarter (the most recent data) had been boosted by an unusual feature of the U.S. statistical system: The output measure used in its calculation is a series for nonfarm business excluding the housing sector. Mortgage refinancing, which jumped in the third quarter, was treated as an intermediate input to the housing sector and, hence, was subtracted from total nonfarm business output to obtain the productivity measure-resulting in a somewhat inflated measure of the productivity increase. President J. Alfred Broaddus (Richmond Fed) noted that the Greenbook projected structural productivity to grow at more than a 2 percent pace in both 2003 and 2004, generating increased profitability, strong cash flows, and firming stock prices-all assisting stronger investment spending. He argued that the forecast's risks likely were weighted toward disappointment, especially regarding productivity growth-the forecast reflected an assumption that multifactor productivity would increase at a rate of $1 \frac{1}{2}$ percent in 2003 and 2004, slightly above even its recent pace.

\section{3}

Robust productivity growth was at the forefront of the Committee's discussions during 2003. While household spending remained modest, business investment spending stubbornly refused to increase. With the federal funds rate target already low, further strong productivity growth threatened additional unwelcome disinflation and, worse, deflation.

The year's first meeting, January 28-29, opened with four presentations regarding monetary policy rules. Although productivity did not enter as a variable in the monetary policy rules in the four opening presentations, it dominated the Committee's discussion thereafter. The staff forecast called for accelerating economic activity after midyear, with stronger trend productivity growth and gains in real income and spending. The label "jobless recovery" reappeared, with staff noting that nonfarm payroll employment during the fourth quarter (of 2002) was less than at the cycle trough (2001:Q4), while labor productivity had increased 3.75 percent. Arguing that recent productivity gains had been achieved by "stretching" existing workers and that hiring would likely improve, the staff anticipated that actual labor productivity would increase at a $13 / 4$ percent pace during 2003-04, somewhat below the projected longer-run trend of a $2^{1 / 4}$ to $2^{1 / 2}$ percent pace.

At the March 18 meeting, the staff found no evidence that productivity growth was slowing. Some members cautioned that the Committee should be wary of the potential for further disinflation if the Iraq war or terrorist attacks caused an economic slowdown. Beyond disinflation concerns, members noted that strong productivity growth would eventually support stronger economic activity. Following the beginning of the Iraq war on March 19, the Committee held telephone conference calls on March 19 and April 1, 8 , and 16 . Productivity was mentioned only infrequently in these discussions, and then only to note its continuing strength and that rapid productivity increases were likely to dampen employment gains.

At the May 6 meeting, the staff noted that rising productivity was allowing firms to shed 
workers more rapidly than might be anticipated during a period of sluggish output growth. The Chairman noted that incoming numbers on production and employment were "awful," but productivity growth was strong despite low capital investment. He suggested that firms had focused on increasing productive capacity during the strong capital investment period of 1995-2000 while largely ignoring increasing inefficiencies"when the spending boom ended in the year 2000, there was a cumulative level of inefficiencies sitting there that were available for exploitation with a relatively modest amount of additional investment."

At the June meeting, the primary topic was monetary policy when overnight nominal interest rates neared their zero lower bound. Staff noted that the then-current federal funds rate target of $1 \frac{1}{4}$ percent placed the Committee in a position it had not experienced for a half century, and presentations focused on unconventional policy tools"shaping interest rate expectations" by committing to maintain the federal funds rate near zero for an extended period and altering both the composition and size of the Federal Reserve balance sheet. Staff discussed simulations of the Federal Reserve Board/U.S. model, suggesting probabilities as high as 40 percent that deflation would occur during 2004 and 2005 (defined as the core PCE index falling a cumulative $1 / 2$ percent or more). The staff noted that productivity accelerations can be self-correcting if the productivity shock increases aggregate demand faster than it increases aggregate supply, a comforting observation but seen as unlikely in the forecasts. The productivity acceleration, once a fortuitous gift to the economy that both reduced inflation and boosted economic activity, risked becoming a scourge.

At the August meeting, however, the staff forecast was upbeat. Aggregate demand growth was stronger and exceeded estimates of the growth of potential (that is, of aggregate supply) with "stunning" productivity increases in the second quarter. Explanations were few. The staff noted that, "The intuition is that, as best we can figure out, a large amount of restraint on the part of employers is an important factor at this moment"the restraint being reflected in sluggish payroll employment growth but rapid productivity growth. The staff projected that hiring would increase and productivity growth slow as business confidence increased, but Committee members' views differed from those of the staff and each other-some argued business confidence was low, others that it was high. The Chairman repeated his opinion that businesses were exploiting opportunities arising from capital investments during 1995-2000: How could it be otherwise with weak capital investment, strong productivity growth, and businesses reporting that intense competition left them no pricing power?

Productivity again was center stage at the September meeting. Incoming data supported the staff's previous forecast of a recovery in economic activity, particularly capital spending, yet the "margin of slack" in labor and product markets was expected to "recede only slowly" over the next two years, with modest wage growth and strong productivity growth resulting in minimal increases in structural unit labor costs and a decrease in headline CPI inflation from 2 percent to 1 percent. Trend productivity was projected to increase in 2004 and 2005, respectively, by $2 \frac{1}{2}$ and $23 / 4$ percent.

The year closed quietly. At the October and December meetings, the staff noted that continuing strong productivity growth had attenuated hiring and placed downward pressure on unit labor costs; in addition, some members saw the high level of slack in labor markets placing further downward pressure on wages, unit labor costs, and inflation.

\section{CONCLUSION}

Growth of productivity has a long history as a discussion topic at Federal Open Market Committee meetings. Unexpectedly strong productivity growth during the early 1980s brought forward arguments foreshadowing those of the following two decades. How much should the Committee risk its price stability goal to gamble that nascent accelerations in productivity would persist? If the Committee were to regard the risk as unacceptable and tighten policy preemptively- 
as suggested by inflation forecast targeting with models that do not incorporate the positive shock to productivity growth-how much output would be lost? And, how does this interact with the FOMC's dual mandate from the Congress to seek both price stability and maximum sustainable employment? The transcripts provide invaluable evidence regarding the real-world dynamics of group decisionmaking under conditions of pervasive uncertainty.

The transcripts make clear that Federal Reserve Chairman Alan Greenspan, relying on anecdotal evidence and disaggregate data, recognized the 1990s productivity acceleration before both the FOMC staff and private forecasters. A significant ingredient was higher earnings that could be explained by no mechanism except unexpectedly rapid productivity growth. Widespread recognition during the mid-1990s of the acceleration of productivity was delayed by weaknesses in measuring productivity. Initial aggregate data for 1995 and 1996, for example, showed little increase in measured productivity. Not until late in the 1990s did revised data vindicate the Chairman's intuition.

Beginning during the mid-1990s, unanticipated productivity growth typically was regarded by the Committee as a benevolent force that atten- uated inflationary pressures by offsetting, in a markup pricing model, largely predetermined increases in wages. During the early 1990s, when employment growth was sluggish and unemployment high, economic activity was boosted by the wealth effects whereby aggregate demand tended to increase before aggregate supply. Sentiment changed during the late 1990s and early 2000s. Then, the Committee became concerned that wealth-induced increases in aggregate demand might cause increased inflation, and the Committee sought to reduce both household and business spending through sharp increases in its target rate. By 2003, slower economic activity turned the tide again, and more-rapid productivity was once again a desired benevolent partner in policy.

The FOMC's experience with productivity growth teaches several lessons. Anecdotal and disaggregate data can be informative, sometimes before changes become apparent in aggregate data. Further, monetary policy, indeed, is an exercise in risk management. Success in risk management sometimes requires some gambling instincts. During the 1990s, the FOMC's gambling paid handsome rewards. Policymaking by committee is difficult, and the skill of a chairman to bring consensus cannot be overvalued. 


\section{REFERENCES}

Anderson, Richard G. and Kliesen, Kevin L. "The 1990s Acceleration in Labor Productivity: Causes and Measurement.” Federal Reserve Bank of St. Louis Review, May/June 2006, 88(3), pp. 181-202; http://research.stlouisfed.org/publications/review/06/05/Anderson.pdf.

Blinder, Alan S. and Reis, Ricardo. "Understanding the Greenspan Standard” at a symposium sponsored by the Federal Reserve Bank of Kansas City, The Greenspan Era: Lessons for the Future, Jackson Hole, Wyoming, August 25-27, 2005; www.kc.frb.org/publicat/sympos/2005/PDF/Blinder-Reis2005.pdf.

Corrado, Carol and Slifman, Lawrence. "Decomposition of Productivity and Unit Costs." American Economic Review, May 1999, 89(2), pp. 328-32.

Friedman, Milton and Schwartz, Anna J. A Monetary History of the United States, 1867-1960. Princeton, NJ: Princeton University Press, 1963.

Greenspan, Alan. "Risk and Uncertainty in Monetary Policy." Remarks at the meetings of the American Economic Association, San Diego, CA, January 3, 2004; www.federalreserve.gov/BoardDocs/Speeches/2004/20040103/default.htm.

Killian, Lutz and Manganelli, Simone. “The Central Banker as a Risk Manager: Estimating the Federal Reserve's Preferences under Greenspan.” Journal of Money, Credit, and Banking, September 2008, 40(6), pp. 1103-29.

Meltzer, Allan H. A History of the Federal Reserve, Volume 1: 1913-1951. Chicago: University of Chicago Press, 2003.

Meyer, Laurence H. A Term at the Fed: An Insider's View. New York: Harper-Collins, 2004.

Sargent, Thomas J. The Conquest of American Inflation. Princeton, NJ: Princeton University Press, 2001.

Taylor, John B. "Commentary: Understanding the Greenspan Standard,” at a symposium sponsored by the Federal Reserve Bank of Kansas City, The Greenspan Era: Lessons for the Future, Jackson Hole, Wyoming, August 25-27, 2005; www.kansascityfed.org/publicat/sympos/2005/PDF/Taylor2005.pdf.

Woodward, Bob. Maestro: Greenspan's Fed and the American Boom. New York: Simon and Schuster, 2000.

Wynne, Mark A. "How Did the Emergence of the New Economy Affect the Conduct of Monetary Policy in the US in the 1990s?" Paper prepared for the International Association for Official Statistics Conference on the New Economy, London, UK, August 27-29, 2002;

www.statistics.gov.uk/IAOSlondon2002/contributed papers/downloads/IP Wynne.pdf. 
